\title{
Effect of Interactive Learning environment on Nursing Students' Engagement and Academic Self-Concept
}

\author{
Ghada Elsayed Abdelhalim ${ }^{1}$, Neama Mohamed Fouad Kamel ${ }^{2}$ Ayah Shaban Abd-El Fattah Abd-EIRasoul $^{3}$ \\ 1, 3 Nursing Education, Faculty of Nursing, Alexandria University \\ 2 Psychiatric Nursing and Mental Health, Faculty of Nursing, Alexandria University.
}

\begin{abstract}
Background: To provoke engagement and higher levels of learning and improving academic self-concept, nurse educators are exploring newer interactive methods of teaching. Nursing educators can create this opportunity by providing diverse settings and activities for interactive learning that is preferred by today's students. Aim: The study aimed to determine the effect of interactive learning environment on nursing students' engagement and academic self-concept. Hypothesis: The students who are instructed through interactive learning environment exhibit more engagement and higher academic self-concept than those who are not. Design: Aquasi-experimental design was used in the current study. Setting: This study was conducted at Faculty of Nursing Alexandria University. Sample: A convenience sampling of 120 nursing students comprised the study subjects. Results: a statistically significant difference, regarding the engagement and the academic self-concept, was found in the favor of the study group. Moreover, a correlation was found between classroom engagement and academic self-concept. Conclusion: The results of the present study support theoretical model which emphasizes the effect of interactive learning environment on students' classroom engagement as well as their academic self-concept. Recommendation: It is necessary to work further as a teacher in developing interactive learning strategies, to improve students' abilities to be more active learners in their educational context and to improve their classroom engagement and academic self-concept.
\end{abstract}

Keywords: Interactive Learning, Classroom Engagement, Academic Self-Concept

\section{Introduction}

Attempts to transition from traditional to active learning are occurring nationally. Nowadays, teachers intersperse questions in lectures to stimulate discussion. However, this is still not active enough. Engagement is a fundamental component of the teacher's actions when desiring to create an environment which stimulates higher levels of learning. Today, students can become more engaged by breaking into various sized groups which work on specific problem-solving, or re-viewing and critiquing-required content articles, or organizing various types of presentations. This integration provides the necessary learning of core content while assisting each other's learning. Instructors can find maintaining a student's engagement level, while delivering various topics, extremely challenging. Therefore, active learning leads to greater engagement than the traditional learning strategies (Hudson 2015).

Students' engagement has three dimensions: first, the behavioral 
engagement, in which students have behavioral norms such as attending and participation. Students in this dimension show absenteeism of negative or disruptive behavior. Second, the emotional engagement, in which students would experience affective responses such as enjoyment, interest and a sense of belonging. Third, the cognitive engagement, in which students would participate in their learning, seek to go beyond the requirements and enjoy challenges (Fredricks et al., 2018).

Emotional engagement includes both positive and negative interaction with teachers, classmates, academics, and school which creates ties to an institution and influences willingness to do the work. Cognitive engagement; draws on the idea of involvement, incorporates thoughtfulness and willingness to exert the effort necessary to comprehend complex ideas and master difficult skills. (Fredricks, McColskey 2012). Academic self-concept constitutes one of the most relevant variables in the academic world, because of its influence on learning and cognitive functioning. It directly affects learning processes, academic achievements, and expectations of students. Additionally, it helps to create various cognitive and self-regulative strategies, which reflect on academic performance. Students with high academic self-concept value their own abilities, accept challenges, take risks, try new things, and also create multiple cognitive strategies . Moreover, they possess a higher motivation to complete difficult academic tasks and set higher goals. In this sense, most students with high academic performance show high academic self-concept (DeDonnol \& Torres 2018).

Academic self-concept can be classified into two major types; positive academic self-concept and negative academic self-concept. Positive academic self-concept is when a person has confidence, good interests, is objective and not too sensitive. This individual may accept the criticism from others and may be able to express their views and opinions. On a differing point, an individual who has negative academic self-concept has a too subjective nature (Abd El Aziz Rady et al., 2016).

Academic self-concept (ASC) is also widely accepted as a critical psychological construct that leads to success in educational settings, nursing schools are facing demands to admit and graduate increasing numbers of students to meet the needs of the future health care system. Nursing schools must therefore admit, retain and graduate qualified applicants, able to provide care in complex healthcare environments. Educators are challenged to identify the best educational practices to retain and engage learners in the learning process. Research has indicated that student engagement contributes to student success in college. Learning environments may influence student engagement through the use of interactive teaching strategies in the classroom (Popkess 2010).

Studies show that active learning promotes improved long-term retention of course material in students. Students tend to have learning styles that make an active environment almost critical to their successful mastery of material. Instructors need pedagogical strategies that provide students with a challenging environment and actively involve them in the learning process. A promising approach, that is gaining space in Computer Science, is active learning. Active learning is typically defined as a method of learning that requires students to be engaged, cognitively and meaningfully, with the courseware (Febrian \& Lawanto 2018). 
This system has long been recognized as an effective way for better learning. Many educators have applied active learning techniques to computer science education. Students can actively learn by reading, writing, discussing, solving problems, or responding to challenging questions. Active learning has been shown to improve student comprehension and retention of material, as well as to increase student motivation and order thinking. Active Learning techniques have been successfully used in Computer Science courses as using screen casting and web 2.0 tools. Web 2.0 tools are internet tools that allow the user to go beyond just receiving information through the web. The user is expected to interact and to create content with others. The tools that are used in this study are Socrative and kahoot and live board (Neo et al., 2013).

To provoke engagement and higher levels of learning and improving academic self-concept, nurse educators are exploring newer interactive methods of teaching. These methods include group work, think-pair-share, peer teaching, and debates. Nursing educators can create this opportunity by providing diverse settings and activities for interactive learning. A strong sense of active learning is preferred by today's students. Hence, the Use of these techniques in the classroom is vital because of their powerful impact upon students' learning. So, the current study supposed that learning environments may influence student engagement through the use of interactive teaching strategies in the classroom which contributes to student engagement and success in college.

\section{Aim of work}

Determine the effect of active learning environment on nursing students' engagement and academic self-concept

\section{Hypotheses of this research are:}

1.The students who are instructed through interactive learning environment exhibit more engagement than those who are not.

2.The students who are instructed through interactive learning environment exhibit higher academic self-concept than those who are not.

\section{Operational Definition:}

- Interactive learning environment: It refers to the application of certain interactive teaching strategies as web 2.0 tools classroom activities (Socrative teachers and students, kahoot softwares for classroom quizzes, online forum discussion, an online real time board, and storyboard).

\section{Subjects and method}

\section{Research design:}

A quasi- experimental research design was used to conduct this study.

Setting: This study was conducted at Faculty of Nursing Alexandria University.

Sample: A convenience sampling of 120 nursing students who were enrolled in advanced computer course at the first and second academic semester of the academic year 2018-2019 comprised the study subjects. The students were randomly assigned into two groups, study and control, 60 students for each.

\section{Tools for data collection:}




\section{Tool I: Nursing Students' Engagement Questionnaire}

It was developed by (Kempler 2005) including 35 items and it was modified to 4 point likert type response format and the degree of agreement was ranged from strongly disagree to strongly agree .Scoring was provided as follow strongly disagree refers to 1 , disagree 2 , agree 3 , and strongly agree 4 .The higher score was represent the higher students' engagement. Socio-demographic characteristics of the students such as students' age, gender, academic achievement, computer skills was attached to this tool. The total scoring system of this scale will be ranged from 35 to 140 and divided into three values in percentages, then distributed as follows:

- Poor level of engagement $=35-<70$

- Fair level of engagement $=\quad 70-<105$

- Good level of engagement $=105-140$ scale

Tool II: Academic self -concept

This scale was first described by (Reynolds 1988) as a measure of an academic facet of general self-concept in college students including 35 items and it was modified to 4 point likert type response format and the degree of agreement was ranged from strongly disagree to strongly agree .Scoring was provided as follow strongly disagree refers to 1 , disagree 2 , agree 3 , and strongly agree 4 . The high score was representing higher academic selfconcept. The total scoring system of this scale will be ranged from 35 to 140 and divided into three values in percentages, then distributed as follows:

- Low level of academic selfconcept $=35-<70$

- Moderate level of academic selfconcept $=70-<105$
- High level of academic selfconcept $=105-140$

\section{Pilot study}

A pilot study was carried out on six students to ensure the clarity and feasibility of the tools, and the necessary modifications was done accordingly prior to data collection. Students included in the pilot were excluded from the study.

\section{Procedure of the study}

An official permission to conduct the study was obtained from Ethical Research Committee at Faculty of Nursing, Alexandria University. An official permission to conduct the study was obtained from the dean of Faculty of Nursing and from head of Nursing Education Department after providing explanation of the aim of the study.

- Tool I and II were tested for their content validity by 5 experts in the related fields (psychiatric and mental health nursing, and nursing education), and then the necessary modifications were done accordingly.

- Reliability was tested for the study tools using Cronbach's alpha test where the result was 0.8 . A written informed consent was obtained from each student who was included in the study. It included the aim of the study, potential benefits from participation. The anonymity, confidentiality of responses, voluntary participation and right to withdraw from the study was emphasized to subjects.

- The researchers collected data at the first semester for control and second for study of the academic year 2018/2019. Students in the two groups were treated 
equally and trained using the same learning objectives except for the nontraditional teaching methods.

- Assessment: The researchers assessed the students for classroom engagement and academic self-concept in the previous courses for both groups through Google Form questionnaires.

Demographic data for both groups were obtained by the researchers.

- Implementation:

\section{For the study group:}

- The theoretical part of advanced computer course: interactive lectures was conducted using brain storming, peer questioning, web 2.0 tools (apps) classroom activities such as story board for clinical module, Socrative, kahoot softwares as quizzes were delivered in a game format using Kahoot and Socrative , answers to each question were explained once the scoreboard appeared on the classroom screen, interactive live board used during online lecture, an online discussion forum were conducted before and after lectures for discussion and feedback, and. Modular Object-Oriented Dynamic Learning Environment (MOODLE) was used as a learning management platform for the course to add resources, activities and to interact with the students and conducting discussion forum.

- The practical part of advanced computer course: included Microsoft Office 2016 software, which contain four modules as following; Word, PowerPoint, Publisher and OneNote. The researchers were developed the following:

- Video recording for each unit using camtigia software.
- Story board and screen casting was structured to illustrate the main features of the program.

- Encouraging more skilled students to help teach those who needed assistance in computer lab

For the control group: students were interacted via traditional teaching methods through lectures in computer lab, practical part of Microsoft office 2016 module.

\section{- Evaluation:}

Students' classroom engagement and academic self-concept were reassessed for both groups immediately after the implementation of interactive learning strategies by using tool I and tool II.

\section{Ethical considerations:}

Return of students' responses through Google Form questionnaires, after explaining the aim of the study, is considered an approval for their participation in the study. Confidentiality of data will be assured. Nursing students voluntary participation and their rights to withdraw from the study will be ascertained at any time without any penalties

\section{Statistical analysis}

Data were fed to the computer and analyzed using IBM SPSS software package version 20.0. (Armonk, NY: IBM Corp) Qualitative data were described using number and percent. Quantitative data were described using mean, standard deviation. Significance of the obtained results was judged at the $5 \%$ level.

\section{Results}


Table (1) summarizes participants' characteristics. In relation to demographic data, more than half of the students of the control and study groups had $20 \leq 22$ years $(56.7 \%, 55 \%)$ respectively. Regarding the sex, it can be observed that $78.3 \%$ and $53.5 \%$ of the study and control groups were female respectively with statistically significant difference. $71.7 \%$ of the control group was in seventh semester, while $58.3 \%$ of study group were in Fifth semester. In relation to last GPA, it can be noticed that nearly one third of both control and study groups had B as last GPA $(35 \%, 30 \%)$ respectively. Regarding students' qualification before joining the faculty, more than three quarters $(80 \%)$ of the control group and nearly two third $(66.7 \%)$ of the study group were secondary school. Moreover, nearly half of both groups $(46.7 \%, 51.7 \%)$ Work beside education. Concerning their working hours, $60.7 \%$ of the control group work $30-<40$ hours per week while, $54.8 \%$ work 40 hours and more per week with statistically significant difference. No statistical significant differences were found between the study and control groups in relation to personal and academic data except in their age, academic semester and working hours per week; this means that both groups were matching.

Table (2) shows comparison between the studied students according to their engagement mean score. It was found that there was a statistically significant difference between study and control groups and within both groups before and after application of interactive learning environment in the favor of the study group where $(\mathrm{P}=0.000)$.

Table (3) illustrates a comparison between the studied students according to their academic self-concept mean scores. It was found that there were a statistically significant difference between study and control groups and within study group before and after application of interactive learning environment in the favor of the study group where $(\mathrm{P}=0.000)$.

Table (4) illustrates the engagement level among the study and control groups before and after the Intervention. It can be noticed that, all students in the study group $(100 \%)$ as compared to most of them $(96.7 \%)$ in the control group had fair level of engagement before the application of interactive learning environment. After intervention, it was noticed that $13.3 \%$ of the students in the study group compared to only $3.3 \%$ of the control group had good engagement level. As regard, there was statistically significant difference between the study and the control groups.

Table (5) illustrates the academic self-concept level among the study and control groups before and after the Intervention. It can be noticed that, all students in both groups (100\%) had moderate level of e academic self-concept before the application of interactive learning environment. After intervention, it was noticed that $8.3 \%$ of the students in the study group compared to $0.0 \%$ of the control group had high level of academic self-concept. As regard, there was statistically significant difference between the study and the control groups.

Table (6) statistically significant correlations were found between engagement and self-concept among the study before and after application of the interactive learning environment $(\mathrm{r}=0.486$, $\mathrm{P}=0.000 \quad$ and $\mathrm{r}=0.424, \quad \mathrm{P}=0.001$ respectively)

Table (7): The same picture was portrayed in table, where there is statistically significant correlation between engagement and self-concept of the control group before and after the 
application of the traditional method

$(\mathrm{r}=0.349, \mathrm{P}=0.006$ and $\mathrm{r}=0.324, \mathrm{P}=0.012$ respectively).

Table (1): Distribution of the studied students according to their personal and academic characteristics

\begin{tabular}{|c|c|c|c|c|c|c|}
\hline \multirow{2}{*}{\multicolumn{2}{|c|}{ Items }} & \multicolumn{2}{|c|}{$\begin{array}{c}\text { Control } \\
\text { group } \\
(\mathbf{n}=60)\end{array}$} & \multicolumn{2}{|c|}{$\begin{array}{l}\text { Study } \\
\text { group } \\
(\mathbf{n}=60)\end{array}$} & $\begin{array}{c}\text { Test of } \\
\text { Significance }\end{array}$ \\
\hline & & No. & $\%$ & No. & $\%$ & \multirow{4}{*}{$\begin{array}{l}\mathrm{X}^{2}=0.373 \\
\mathrm{P}=0.830\end{array}$} \\
\hline \multirow{4}{*}{ Age } & $20-$ & 34 & 56.7 & 33 & 55.0 & \\
\hline & $22-$ & 21 & 35.0 & 20 & 33.3 & \\
\hline & $24-26$ & 5 & 8.3 & 7 & 11.7 & \\
\hline & $($ Mean $\pm \mathrm{SD})$ & \multicolumn{2}{|c|}{$21.65 \pm 1.273$} & \multicolumn{2}{|c|}{$21.60 \pm 1.343$} & $\begin{array}{l}t=0.209 \\
P=0.835\end{array}$ \\
\hline \multirow[t]{2}{*}{ Sex } & Male & 13 & 21.7 & 28 & 46.7 & $\mathrm{X}^{2}=8.336$ \\
\hline & Female & 47 & 78.3 & 32 & 53.3 & $\mathrm{P}=0.004 *$ \\
\hline Academic & Third & 1 & 1.7 & 11 & 18.3 & $X^{2}=30.166$ \\
\hline \multirow[t]{2}{*}{ Semester } & Fifth & 16 & 26.7 & 35 & 58.3 & $\mathrm{P}=0.000^{*}$ \\
\hline & Seventh & 43 & 71.7 & 14 & 23.3 & \\
\hline \multirow[t]{8}{*}{ Last GPA } & A & 3 & 5.0 & 0 & 0.0 & \multirow{8}{*}{$\begin{array}{l}X^{2}=9.720 \\
P=0.205\end{array}$} \\
\hline & A- & 2 & 3.3 & 4 & 6.7 & \\
\hline & $\mathrm{B}+$ & 9 & 15.0 & 15 & 25.0 & \\
\hline & B & 21 & 35.0 & 18 & 30.0 & \\
\hline & B- & 13 & 21.7 & 14 & 23.3 & \\
\hline & $\mathrm{C}+$ & 9 & 15.0 & 3 & 5.0 & \\
\hline & $\mathrm{C}$ & 2 & 3.3 & 5 & 8.3 & \\
\hline & $\mathrm{C}-$ & 1 & 1.7 & 1 & 1.7 & \\
\hline \multirow{9}{*}{$\begin{array}{l}\text { Qualification } \\
\text { before joining } \\
\text { the faculty } \\
\text { Work beside } \\
\text { education } \\
\text { Working hours }\end{array}$} & Secondary school & 48 & 80.0 & 40 & 66.7 & \multirow{2}{*}{$\begin{array}{l}X^{2}=2.727 \\
P=0.099\end{array}$} \\
\hline & Technical Institute of Nursing & 12 & 20.0 & 20 & 33.3 & \\
\hline & No & 32 & 53.3 & 29 & 48.3 & \multirow{6}{*}{$\begin{array}{l}X^{2}=0.3001 \\
P=0.584 \\
X^{2}=11.090 \\
P=0.004^{*}\end{array}$} \\
\hline & Yes & 28 & 46.7 & 31 & 51.7 & \\
\hline & & \multicolumn{2}{|c|}{$\mathrm{N}=28$} & \multicolumn{2}{|c|}{$\mathrm{N}=31$} & \\
\hline & $20-$ & 5 & 17.9 & 8 & 25.8 & \\
\hline & $30-$ & 17 & 60.7 & 6 & 19.4 & \\
\hline & $40+$ & 6 & 21.4 & 17 & 54.8 & \\
\hline & $($ Mean \pm SD) & 16.9 & 2.113 & 39.6 & $=5.014$ & $\begin{array}{l}\mathrm{t}=32.402 \\
\mathrm{P}=0.000^{*}\end{array}$ \\
\hline \multirow{2}{*}{$\begin{array}{l}\text { Nature of work } \\
\text { (nursing } \\
\text { related) }\end{array}$} & No & 0 & 0.0 & 0 & 0.0 & \multirow{2}{*}{$\begin{array}{l}X^{2}=\text {-------- } \\
P=\text {-------- }\end{array}$} \\
\hline & Yes & 28 & 100.0 & 31 & 100.0 & \\
\hline
\end{tabular}


(Table 2): Comparisons between the studied groups according to their engagement mean scores before and after application of active learning environment

\begin{tabular}{|c|c|c|c|c|c|c|c|c|}
\hline \multirow[t]{2}{*}{$\begin{array}{c}\text { Item } \\
\mathbf{s}\end{array}$} & \multicolumn{2}{|c|}{$\begin{array}{l}\text { Study group } \\
\text { Engagement } \\
\text { Mean Scores }\end{array}$} & \multirow[t]{2}{*}{$\mathbf{T}(\mathbf{P})$} & \multicolumn{2}{|c|}{$\begin{array}{l}\text { Control group } \\
\text { Engagement } \\
\text { Mean Scores }\end{array}$} & \multirow[t]{2}{*}{$\mathbf{T}(\mathbf{P})$} & \multirow[t]{2}{*}{$\begin{array}{c}\text { Study/ } \\
\text { Contro } \\
\text { I } \\
\text { (Pre) }\end{array}$} & \multirow[t]{2}{*}{$\begin{array}{c}\text { Study/ } \\
\text { Contro } \\
\text { l } \\
\text { (Post) }\end{array}$} \\
\hline & Pre & Post & & Pre & Post & & & \\
\hline $\begin{array}{c}\text { Min- } \\
\text { Max } \\
\text { Mea } \\
\text { n } \pm \\
\text { SD }\end{array}$ & $\begin{array}{c}89.03 \pm 5.15 \\
2\end{array}$ & $\begin{array}{c}99.68 \pm 5.01 \\
3\end{array}$ & $\begin{array}{c}11.47 \\
6 \\
(0.000 \\
)^{*}\end{array}$ & $\begin{array}{c}89.50 \pm 6.00 \\
7\end{array}$ & $91.95 \pm 5.482$ & $\begin{array}{c}2.334 \\
(0.021) *\end{array}$ & $(0.646)$ & $\begin{array}{c}8.060 \\
(0.000) \\
*\end{array}$ \\
\hline
\end{tabular}

T student $\mathrm{t}$ test * statistically significant at $\mathrm{p} \leq 0.05$

Table (3): Comparisons between the studied groups according to their selfconcept mean scores before and after application of active learning environment

\begin{tabular}{|c|c|c|c|c|c|c|c|c|}
\hline \multirow[t]{3}{*}{ Items } & \multirow{2}{*}{\multicolumn{2}{|c|}{$\begin{array}{l}\text { Study group } \\
\text { Self-Concept } \\
\text { Mean Scores }\end{array}$}} & $\mathbf{T}(\mathbf{P})$ & \multirow{2}{*}{\multicolumn{2}{|c|}{$\begin{array}{l}\text { Control group } \\
\text { Self-Concept } \\
\text { Mean Scores }\end{array}$}} & \multirow[t]{3}{*}{$\mathbf{T}(\mathbf{P})$} & \multirow{3}{*}{$\begin{array}{l}\text { Study/ } \\
\text { Contr } \\
\text { ol } \\
\text { (Pre) }\end{array}$} & \multirow{3}{*}{$\begin{array}{l}\text { Study/ } \\
\text { Contr } \\
\text { ol } \\
\text { (Post) }\end{array}$} \\
\hline & & & & & & & & \\
\hline & Pre & Post & & Pre & Post & & & \\
\hline $\begin{array}{l}\text { Min- } \\
\text { Max }\end{array}$ & $96-115$ & 100-119 & 7.092 & $92-115$ & $92-115$ & \multirow{2}{*}{$\begin{array}{c}0.025 \\
(0.980)\end{array}$} & 1.273 & \multirow{2}{*}{$\begin{array}{c}7.962 \\
(0.000) \\
*\end{array}$} \\
\hline $\begin{array}{c}\text { Mean } \pm \\
\text { SD }\end{array}$ & $\begin{array}{c}102.19 \pm 3.9 \\
15\end{array}$ & $\begin{array}{c}108.27 \pm 5.3 \\
64\end{array}$ & $\begin{array}{c}(0.000 \\
)^{*}\end{array}$ & $101.22 \pm 4.420$ & $101.20 \pm 4.305$ & & $(0.206)$ & \\
\hline
\end{tabular}

T student $t$ test $*$ statistically significant at $\mathrm{p} \leq 0.05$

Table (4): Comparison between the studied groups according to their engagement levels before and after application of active learning environment

\begin{tabular}{|c|c|c|c|c|c|c|c|c|c|c|c|c|}
\hline \multirow{3}{*}{ Levels } & \multicolumn{4}{|c|}{ Study group } & \multirow{3}{*}{$\begin{array}{l}X^{2} \\
(P)\end{array}$} & \multicolumn{4}{|c|}{ Control group } & \multirow{3}{*}{$\begin{array}{l}X^{2} \\
(P)\end{array}$} & \multirow{3}{*}{$\begin{array}{c}\text { Study/ } \\
\text { Control } \\
\text { (Pre) }\end{array}$} & \multirow{3}{*}{$\begin{array}{c}\text { Study/ } \\
\text { Control } \\
\text { (Post) }\end{array}$} \\
\hline & \multicolumn{2}{|c|}{ Pre } & \multicolumn{2}{|c|}{ Post } & & \multicolumn{2}{|c|}{ Pre } & \multicolumn{2}{|c|}{ Post } & & & \\
\hline & No. & $\%$ & No. & $\%$ & & No. & $\%$ & No. & $\%$ & & & \\
\hline Poor & 0 & 0.0 & 0 & 0.0 & 8.571 & 0 & 0.0 & 0 & 0.0 & ------- & 2.034 & 3.927 \\
\hline Fair & 60 & 100.0 & 52 & 86.7 & $(0.003)^{*}$ & 58 & 96.7 & 58 & 96.7 & & $(0.154)$ & $(0.048) *$ \\
\hline Good & 0 & 0.0 & 8 & 13.3 & & 2 & 3.3 & 2 & 3.3 & & & \\
\hline
\end{tabular}

$\mathrm{X}^{2}$ Chi Square test $*$ statistically significant at $\mathrm{p} \leq 0.05$

Table (5): Comparison between the studied groups according to their selfconcept levels before and after application of active learning environment

\begin{tabular}{|c|c|c|c|c|c|c|c|c|c|c|c|c|}
\hline \multirow{3}{*}{ Levels } & \multicolumn{4}{|c|}{ Study group } & \multirow{3}{*}{$\begin{array}{l}X^{2} \\
(\mathrm{P})\end{array}$} & \multicolumn{4}{|c|}{ Control group } & \multirow{3}{*}{$\begin{array}{l}\mathrm{X}^{2} \\
(\mathrm{P})\end{array}$} & \multirow{3}{*}{$\begin{array}{c}\text { Study/ } \\
\text { Control } \\
\text { (Pre) }\end{array}$} & \multirow{3}{*}{$\begin{array}{c}\text { Study/ } \\
\text { Control } \\
\text { (Post) }\end{array}$} \\
\hline & \multicolumn{2}{|c|}{ Pre } & \multicolumn{2}{|c|}{ Post } & & \multicolumn{2}{|c|}{ Pre } & \multicolumn{2}{|c|}{ Post } & & & \\
\hline & No. & $\%$ & No. & $\%$ & & No. & $\%$ & No. & $\%$ & & & \\
\hline Low & 0 & 0.0 & 0 & 0.0 & 5.217 & 0 & 0.0 & 0 & 0.0 & ------- & -------- & 5.217 \\
\hline Moderate & 60 & 100.0 & 55 & 91.7 & $(0.022)^{*}$ & 60 & 100.0 & 60 & 100.0 & - & & $(0.022)^{*}$ \\
\hline High & 0 & 0.0 & 5 & 8.3 & & 0 & 0.0 & 0 & 0.0 & & & \\
\hline
\end{tabular}

$\mathrm{X}^{2}$ Chi Square test $*$ statistically significant at $\mathrm{p} \leq 0.05$ 
Table (6): Correlation Matrix between engagement and self-concept among the study group

\begin{tabular}{|lccccc|}
\hline Engagement & R & $\begin{array}{c}\text { Engagement } \\
\text { Pre }\end{array}$ & $\begin{array}{c}\text { Self. Concept } \\
\text { Pre }\end{array}$ & $\begin{array}{c}\text { Engagement } \\
\text { Post }\end{array}$ & $\begin{array}{c}\text { Self. Concept } \\
\text { Post }\end{array}$ \\
Pre & & & & \\
Self. Concept & $\mathrm{P}$ & $\mathrm{R}$ & 0.486 & & \\
Pre & $\mathrm{P}$ & $0.000^{*}$ & & \\
Engagement & $\mathrm{R}$ & 0.929 & 0.429 & \\
Post & $\mathrm{P}$ & $0.000^{*}$ & $0.001^{*}$ & & \\
Self. Concept & $\mathrm{R}$ & 0.480 & 0.995 & 0.424 \\
Post & $\mathrm{P}$ & $0.000^{*}$ & $0.000^{*}$ & $0.001^{*}$ & \\
\hline
\end{tabular}

$\mathrm{r}=$ Correlation coefficient $*$ statistically significant at $\mathrm{p} \leq 0.05$

Table (7): Correlation Matrix between engagement and self-concept among the control group

\begin{tabular}{|lccccc|}
\hline Engagement & R & $\begin{array}{c}\text { Engagement } \\
\text { Pre }\end{array}$ & $\begin{array}{c}\text { Self. Concept } \\
\text { Pre }\end{array}$ & $\begin{array}{c}\text { Engagement } \\
\text { post }\end{array}$ & $\begin{array}{c}\text { Self. Concept } \\
\text { Post }\end{array}$ \\
Pre & & & & \\
Self. Concept & $\mathrm{P}$ & $\mathrm{R}$ & 0.349 & & \\
Pre & $\mathrm{P}$ & $0.006^{*}$ & & & \\
Engagement & $\mathrm{R}$ & 0.066 & 0.236 & & \\
Post & $\mathrm{P}$ & 0.616 & 0.069 & & \\
Self. Concept & $\mathrm{R}$ & 0.046 & 0.149 & 0.324 & \\
Post & $\mathrm{P}$ & 0.729 & 0.254 & $0.012^{*}$ & \\
\hline
\end{tabular}

$\mathrm{r}=$ Correlation coefficient $*$ statistically significant at $\mathrm{p} \leq 0.05$

\section{Discussion}

Since technology has become integrated into in our daily life, interactive lecturing with technology has become ground breaking advancement in education. Technology has been proven to improve learning outcomes, students' academic self-concept and engagement (Vaughan, Zommer\& Villamer 2020). Interactive learning environment utilizing learning technologies can make transition of pedagogy from an instructor-centered passive to a student-centered active learning environment. In recent years, Interactive learning model based on constructivism theory has drawn attention all over the world (Chuang 2014; Sternberger 2012).
The main goal of this study was to provide a set of useful tools for promoting nursing students 'engagement and academic self-concept. In this study, the teaching strategies were organized based on the similarities of concepts and teaching techniques that educators had used. These strategies were interactive lectures using brain storming, peer questioning and peer learning in computer labs as well as technology-based strategies through using web 2.0 tools (apps) classroom activities such as; socrative, kahoot software for classroom quizzes, interactive live board, an online discussion forum, story board, screen casting and video recording. Modular Object-Oriented Dynamic Learning Environment (MOODLE) was used as a learning management platform for the advanced computer course. 
The finding of the current study revealed that, significant differences were seen between the control and study groups in engagement and academic self-concept after the intervention. Moreover, it showed that the engagement and academic self-concept level after intervention was better in the study group while it was not seen in the control group.

From the researchers' point of view, the result of the current study may be attributed to many reasons; among which are; the use of interactive learning strategies. Therefore, active learning is both an individual process and an experience of participating with other members. It improves students' social integration, their attitude toward the subject and their engagement with their studies and the academic institution, which consequently creates a competitive learning environment. Comparing with the previous generations of students, the digitally-native students tend to be more active experimental learners, more proficient in multitasking, and strongly dependent on communication technologies for accessing information and for interacting with others. Interactive learning tools are more favorable in order to create enjoyable and interesting interaction to boost student motivation

Furthermore, online forum discussion can bridge the gap between theory and practice in nursing discipline as well as it can facilitate the process of nursing students' engagement and academic self-concept. Posting a series of questions on the discussion forums encouraged those students to reflect and respond actively to those questions enhanced their engagement.

Another reason was that students were highly motivated and excited to the idea and new instructional methods. It also promoted active learning, and learning from peers, it also improved their confidence, and supported diverse learning styles and different levels. In addition, the application of different technology-based strategies attracted the students to learn and helped them further on improving their engagement and academic self-concept.

This finding was supported by (Ghasemi et al., 2020) who reported that using online (Kahoot and synchronous discussion boards) and offline technologies in and outside the classroom promoting nursing students' engagement. This was similarly consistent with finding of (Hsu 2011) who reported that an interactive learning tool is more favorable in order to create enjoyable and interesting interactions to boost student motivation. National survey of student's engagement (2009) noted a significant relation between engagement and interactive learning. This is in line with (Srinivas, 2014) who concluded that collaborative learning promotes positive attitudes toward subject matter, improving students' teamwork skills, encouraging more in-class participation, promoting greater in-class attention, creating more in-class interaction, and developing higher-order thinking.

In addition, Ignacio and (Chen 2020) reported that using a web-based platform like Kahoot! is an engaging strategy to make learning meaningful. It has the potential to build an engaging learning environment. Academic selfconcept and engagement were developed as students actively participate in a student-centered activity that motivates them to learn while having fun.

(Neo et al., 2013) Results showed that using web 2.0 as a mediating component in the instructional process was interesting and effective for the student learning process and the 
Conversational Framework was successfully adapted in this learning environment.

(Waheed 2017) in his study concluded that, student participation in class activities and an online discussion forum improves students' engagement and learning and this in turn gives them a sense of belonging. They acted as creative learners and active learners, and gave their opinions and ideas in the group, something which was lacking in the conventional teaching and learning classrooms

(AlJeraisy M et al., 2015) Results showed that there is a positive impact of discussion forum on students' grades and student's satisfaction as it enables student to interact, collaborate and exchange knowledge in different online courses

(Simonsmeier B et al., 2020) reported that Peer assessment or feedback has been shown to be an effective strategy to improve academic achievement and students' academic self-concept in higher education

On the contrary, (Hede 2002) debates on whether multimedia improves learning. Some research report that multimedia increases learning, while others report that multimedia is not the only factor that increases learning. (Hede,Hede 2002) .This difference may be because the college students in the contradicting study are not as familiar with multimedia. Another justification may be due to different learning styles and preferences of students.

Academic self-concept constitutes one of the most relevant variables in the academic world, because of its influence on learning and cognitive functioning. It directly affects learning processes, academic achievement, and expectations of students. It has been recognized that perceived academic power is a significant factor in the academic performance of college students (Hede 2002; Hede,Hede 2002).

Student participation and cognitive and emotional engagement in learning activities play a key role in student academic achievement and are driven by student motivational characteristics such as academic self-concept. Academic selfconcept and classroom engagement are strong predictors of each other, and have been documented to promote the academic engagement of students. Individuals with a low academic selfconcept have shown low classroom engagement (Schnitzler, Holzberger 2020).

The present study findings indicate a significant correlation between classroom engagement and academic selfconcept of nursing students before and after the intervention. Students with higher academic self-concept were more likely to show a pattern of moderate to high engagement. Based on the found link and positive relation between school engagement and students' academic selfconcept that was also confirmed, significant positive correlations between the target variables are presented in multiple studies. These studies revealed that engagement is associated with a positive academic self-concept. Both variables play a fundamental role in the school environment (Schnitzler, Holzberger 2020; Supervia, Bordas, Lorente 2020; Babatunde, Olanrewaju 2014; Sinna 2016; Gemeay et al. 2013; Black, Deci 2000; Green, Liem, Martin, Colmar 2012).

In the same line with the current study, (Galugu 2019) examined the role of academic self-concept as the moderate variable on the relationship between 
teacher's support and students' engagement in school. The results showed that the relationship between the teacher's support and students' engagement in school is increasingly strengthened by the presence of academic self-concept as a moderated variable. The positive selfconcept among the students develops student's self-regulation and achievement academics and automatically increases student's engagement in the learning process.

\section{Conclusion:}

Students' engagement and selfconcept in academic-related learning activities is one of the important determinants of students' success. Identifying the best teaching strategies to sustain and promote nursing students' engagement and self-concept in academic and clinical settings has always been a challenge for nurse educators. Hence, it is essential to provide a set of strategies for maintaining and enhancing the academic engagement of nursing students. Among the strategies discussed in this study, the use of technology which is in line with today's advances in smart technologies. In addition, the results of the present study support theoretical model which emphasizes the effect of interactive learning environments on students' engagement level as well as their academic self-concept. It is necessary to work further as a teacher in developing interactive learning strategies, to improve students' abilities to be more active learners in their educational context.

\section{Pedagogical implications}

Our results suggest that in order to enhance students' engagement and academic self-concept, more coherent learning environments offering opportunities for students to participate in both academic activities and peer interaction need to be developed. In particular, the use of more activating pedagogic practices through technology in and outside classroom need to be facilitated to promote student participation.

\section{Future Researches}

- Further experimental research is needed to confirm or disprove the effectiveness of the interactive learning environment on promoting engagement and academic self-concept in clinical setting.

- Future research based on longitudinal nature may better determine the causal nature of the relationships between classroom engagement and academic self-concept.

- Explore qualitatively about other factors which influence student's engagement in the learning environment.

\section{Conflict of interest}

There were no conflicts of interest.

\section{Funding}

The author(s) received no financial support for the research, authorship, and/or publication of this article

\section{References:}

AlJeraisy, M., Mohammad, H., Fayyoumi, H., Alrashideh, W.(2015). Web 2.0 in Education: The impact of discussion board on student performance and satisfaction. The Turkish Online Journal of Educational Technology ;14 (2):.247-258. 
Babatunde, M., Olanrewaju, M.(2014) .Predictive influence of students' academic engagement and academic self-concept on achievement motivation among post graduate students in University of Ibadan, Oyo State, Nigeria. International Journal of Science and Research; 3 (5): 497-502.

Black, E., Deci, L.(2000). The effects of instructors' autonomy support and students' autonomous motivation on learning organic chemistry: A selfdetermination theory perspective. Science Education; 84: 740-756.

Rady, H., Kabeer, S., El-Nady M. (2016). Relationship between academic self-concept and students' performance among school age children. American Journal of Nursing Science; 5(6): 295-302.

Briggs, T.(2005). Techniques for active learning in CS courses. Journal of Computing Sciences in Colleges; 21(2):156-65.

Neo, M., Neo, K., Lim, T., Tan, H., Kwok, W.(2013). Instructional relationships within a web-based learning environment: Students' perceptions in a Malaysian classroom. Social and Behavioral Sciences Journal ; 103:515-525

Carter, P. (2009). An experiment with online instruction and active learning in an introductory computing course for engineers: Jitt meets CS1.Publication:WCCCE '09: Proceedings of the 14th Western Canadian Conference on Computing Education. 103-108. Available at https://doi.org/10.1145/1536274.1536 305

Chuang, T. (2014). Increasing learning motivation and student engagement through the technology supported learning environment. Creative Education Journal; 5:1969-1978.

DeDonno, M., Torres, K. (2018). The influence of perfectionism on academic self-concept. International Journal of Education and Practice; 6(4): 192-199.

Falkner, K., Vivian, R., Falkner, N. (2014). Identifying computer science self-regulated learning strategies. In proceedings of the 2014 conference on innovation \& technology in computer science education. Available at:

http://doi.org/10.1145/2591708.25917 15.

Febrian, A., Lawanto, S. (2018). Do computer science students understand their programming task?:A case study of solving the Josephus variant problem. International Education Studies; 11(12):26.

Fredricks, A., Blumenfeld, C., Paris, H. (2018). School engagement: Potential of the concept and state of the evidence. Journal of Review of Educational Research, 74 (1), 59-109.

Fredricks, A., McColskey, W.(2012). The measurement of student engagement: A comparative analysis of various methods and student selfreport instruments. Handbook of Research on Student Engagement ;1(3): 763-782 available at

https://link.springer.com/chapter/10.1007 \%2F978-1-4614-2018-7-3

Galugu, N., Samsinar ,S.(2019). Academic self-concept, teacher's supports and student's engagement in the school. Journal of Educational 
Psychology and Counseling;5(2): 141147.

Gemeay, E., Behilak, S., Kanona, A., Essmat, A. (2013). Self-concept and academic achievements among nursing students. Life Science Journal;10 (1):1466-1470.

Ghasem, M., Moonaghi, H., Heydari, A.(2020). Strategies for sustaining and enhancing nursing students' engagement in academic and clinical settings: A narrative Review.Korean Medical Education Journal;23(2):103117.

Green, J., Liem, G., Martin, A., Colmar, S .(2012).Academic motivation, self-concept, engagement, and performance in high school: Key processes from a longitudinal perspective, Journal of Adolescence; 35(5):11-22.

Guzdial, M., Johnson, R., Wampler, K., Kussmaul, C., Swanson, J., Humenn, P., Lewchuk, M. (2015). What's the best way to teach computer science to beginners? Communications of the ACM; 58(2): 12-13.

Hede, A.(2002). An integrated model of multimedia effects on learning. Journal of Educational Multimedia and Hypermedia; 11: 177-191.

Hede, T., Hede, A.(2002). Multimedia effects on learning: design implications of an integrated model. In S. McNamara and E. Stacey (Eds), untangling the web: Establishing learning links. Proceedings ASET Conference, Melbourne, Australia. Available at:

https://www.researchgate.net/publication/ 272622980_Multimedia_effects_on_1
earning_Design_implications_of_an_i ntegrated_model

Hsu, J.(2011). The potential of kinect in education.International Journal of Information and Education Technology; 1 (5):. 365-370,2011

Hudson, K. (2015). Nursing student engagement: student, classroom, and clinical engagement .International Journal of Nursing; 4(1): 44.

Ignacio, J., Chen, H . (2020). The use of web-based classroom gaming to facilitate cognitive integration in undergraduate nursing students: A mixed methods study.Nurse Education in Practice;26(1):.....

https://www.sciencedirect.com/science/ar ticle/abs/pii/S1471595318309612

Kempler, D. (2005). Best practice in outcomes-based teaching and learning at the chinese university of hong kong. Carmel McNaught, Centre for Learning Enhancement and Research.1-18.

\section{National Survey of Student} Engagement. (2009): Assessment for improvement: Tracking student engagement over time-annual results. Available at:

http://hdl.handle.net/2022/23410

Neo, M., Neo, K., Lim, T., Tan, H., Kwoke, W. 2013. Instructional relationships within a web-based learning environment: Students' perceptions in a Malaysian classroom. Procedia - Social and Behavioral Sciences $103.515-525$

Popkess, M.(2010). The relationship between undergraduate, baccalaureate nursing student engagement and use 
of active learning strategies in the classroom. Doctoral Dissertation, faculty of the University Graduate Indiana University.

Reynolds, W.(1988).Measurement of academic self-concept in college students. Journal of Personality Assessment; 52(2):223-240

Schnitzler, K., Holzberger, D., Seidel, T. (2020). All better than being disengaged: student engagement patterns and their relations to academic self-concept and achievement. European Journal of Psychology of Education .Avilable at:

https://link.springer.com/article/10.1007/s 10212-020-00500-6

Simonsmeier, B., Peifer,H., Flaig, M., Schneider, M.(2020). Peer feedback improves students' academic selfconcept in higher education. Research in Higher Education. 61:706-724

Sinna R. (2016). What's it like on the inside? The impact of self-concept on the educational engagement and delinquency of young offenders in a custodial setting. Doctoral Dissertation. Faculty of Health, Arts and Design. Swinburne University of Technology.
Srinivas, H. (2014).Collaborative Learning. Available at:

http://www.gdrc.org/kmgmt/c-learn

Sternberger, S.(2012). Interactive learning environment: engaging students using clickers. Nursing Education Perspective; 33(2):121-124

Supervía , P., Bordás, C., Lorente, V . (2020). The mediating role of goal orientation (task) in the relationship between engagement and academic self-concept in students. International Journal of Environmental Research and Public Health; 2020: 17(22): 8323.

Vaughan, N., Zimmer, J., Villamer F. (2020). Student's engagement and interactive technologies: what's the connection? International journal of excellence in e-learning; 4(1):115-121.

Waheed, N.(2017).Effects of an online discussion forum on student engagement and learning in a first year undergraduate nursing unit an action research study. Conference paper available at:

https://www.researchgate.net/publication/ 318824025 